\title{
Health \& Safety issues and Harassment at workplace in select Garment Industries of Bengaluru City
}

\author{
Dr. Hemamalini, M.J
}

Abstract-The garment industries in Karnataka are concentrated in Bangalore where some of the largest export houses of the Country are existing.About $80 \%$ of garment workers in Bengaluru have always been from rural areas, but now there are more interstate migrations. In the past five years, the fashion industry's requirements for cheaper and faster labour have prompted garment companies to focus on rural India - by recruiting migrant workers from distant villages in eastern and central India, and relocating Bengaluru factories to villages in South India.

The present study is an attempt to assess the health \& safety issues and psychological harassment of workers in Garment Industry of Bangalore City. Few industries were chosen for the study wherein women workers were more in number compared to male workers. The researcher conducted a preliminary sample study by way of discussions and interviews with the selected workers, management personnel, and working committee members. This empirical study was conducted on a random sample survey of the workers base of the garments at Bangalore city. The researcher selected 6 Garment Industries for the study based on few inclusion criteria with 480 workers as sampling size. They were assessed on several of health and safety issues on one hand, and harassment in different aspects on the other hand. Both the issues were assessed through semi structured questionnaire developed and validated by the researcher. The results were analyzed through both descriptive and inferential statistics. Results revealed that all the facilities related to health and safety was addressed $100 \%$ including no restriction to use bathroom facilities. Most of crèche and canteen facilities were maintained except for restrictions to workers to leave the child in crèche $(79.1 \%)$. Majority of the workers (94.6) mentioned that they were not satisfied with the hygienic conditions of the canteen. Only $1 / 8$ (12.5\%) of the respondents indicated physical, psychological, secular and verbal harassment. It is evident that, health and safety measures still to be improved in garment factories and harassment need to be reduced. Strategies for improving quality of life of the garment workers and reducing the harassment at work place have been delineated.

Keywords - Garment workers, health and safety, harassment

\section{Dr Hemamalini, M.J}

Assistant Professor/Placement Officer

Maharani Lakshmi Ammanni College for women

$18^{\text {th }}$ Cross, Malleshwaram, Bangalore- 1

India

\section{Introduction}

Readymade garment Industry plays a vital role in the basic need of every citizen. It is second largest revenue earner from export of Readymade garments from India. It offers employment opportunities to both skilled and unskilled labour force. Despite many studies being done on this subject, there is a dearth for research studies on compliance and social audit among the industries situated in and around Bangalore area.Though less known than its IT counterpart, the garment industry in Bangalore is a major source of livelihood for about half a million workers. Its contribution to the economy of Karnataka state is considerable. The dire working conditions in the industry and workers' lack of access to basic facilities and benefits have often been cited in news reports and studies, including those by Cividep. With the overwhelming majority of workers in the sector being women, the well-known cycle of exploitation at the workplace, low pay, poor social security, occupational hazards and the social burden of having to look after the family and manage the home prove to be oppressive(Padmini\&Venmathi ${ }^{1}$, 2012; Joseph \&Kiran ${ }^{2}$, 2008).

India has many challenges on the industrial front to mention the key areas that regulate conditions in the workplace are daunting. Public policies on health and safety, gender discrimination, basic work conditions, rampant child labour cover millions of workers. Work regulations have to be implemented in hundreds of thousands of readymade garment industries situated in different geographic settings. Conditions within those workplaces vary enormously - even within a single industry - and employers often face dilemma to make those conditions as clear as possible (Shanbhag\& Joseph $^{3}$, 2012).

The majority of worker section belongs to lesser educational level, find difficulty in understanding the concept of compliance and its practice; this is taken as an advantage by the policy makers and its executors. This may lead to discrepancy between the company policy and its day today practice with this background, in the present study researcher attempts to find out the extent of facilities available and harassment if any, for this downtrodden workforce.

Studies in this line have revealed the following. Study in Nepal by Adhikari, Hirasawa, Takakubo, and Pandey ${ }^{4}$ (2012),indicate that currently, although the country has been successful in reducing the number of people under the poverty line, there are challenges in Imeeting the decent work goals. In the case of quality of work life (QWL), since there is rising dissatisfaction among employers and employees in the present economic and political circumstances, they are interested in short-term benefits. 
Adhikari $^{5}$ (2012), opines that the cases presented in the paper show a low intensity of CSR in Nepal. Both government and employers are somehow not serious in implementing labor laws. At the company level, employees' awareness of CSR can bring a positive attitude towards the company.

The present study is to assess the health and safety conditions of garment workers on the one hand, and the harassment they experience on the work place on the other hand. It is hypothesized that the health and safety conditions of these garment workers are not up to the mark and these garment workers do suffer from harassment.

\section{Method}

\section{Universe and sample}

There are more than 90 units which employees more than 300 workers in Bangalore city. For the purpose of the study only 5 units which have employees strength of more than 500 in each unit has been selected, the name of the units have been kept confidential. For the purpose of research, primary data has been collected through the questionnaire and interview method. In total 480 employees has been involved through questionnaire and interview which is more than $5 \%$ of the selected population.

\section{Tool employed:}

The researcher had developed semi structured questionnaire on health and safety facilities and harassment undergone by the garment factory employees. In the questionnaire, important factors of welfare measures like health and hygiene, work place safety, canteen and crèche are emphasized. Also few of the questions included various issues on harassment.

\section{Procedure}

A pilot study has been conducted and its review reflected the need for improvement in the facilities provided to employees.

Once the pilot study is over, necessary corrections were made for the questionnaire and full data were collected from a sample 480 employees, selected randomly from 6 garment factories.

This primary selection was coupled with the discussions and interviews with the selected workers, management personnel, working committee members from the Bangalore based selected garment industries - to cater subtle information regarding the subject matter of research.

For analysis of the data, the statistical tool like frequencies and percentages are employed and chi-square test was used as inferential statistics.

\section{Results}

Tables 1 and 2 present the analysis of results obtained by the study. The detailed descriptions along with tables are given in the following pages:

\section{Facilities}

Table 1

Frequency and percent responses for various statements on Health \& Safety Requirements and results of chi-square tests

\begin{tabular}{|c|c|c|c|c|c|}
\hline Facilities & & Yes & No & $\begin{array}{l}\text { Not } \\
\text { aware }\end{array}$ & $\begin{array}{l}\text { Chi- } \\
\text { square }\end{array}$ \\
\hline \multirow{2}{*}{$\begin{array}{l}\text { Pregnant workers } \\
\text { given proper care } \\
\& \text { treatment. }\end{array}$} & $\mathrm{F}$ & 244 & 17 & - & \multirow[t]{2}{*}{$193.66 *$} \\
\hline & $\%$ & 93.5 & 6.5 & - & \\
\hline \multirow{2}{*}{$\begin{array}{l}\text { Maintenance of job } \\
\text { position, wage \& } \\
\text { benefits } \\
\text { maternity. }\end{array}$} & $\mathrm{F}$ & 466 & 12 & 2 & \multirow[t]{2}{*}{$878.15 *$} \\
\hline & $\%$ & 97.1 & 2.5 & .4 & \\
\hline \multirow[t]{2}{*}{ ESI Coverage } & $\mathrm{F}$ & 478 & 12 & 2 & \multirow[t]{2}{*}{$472.03 *$} \\
\hline & $\%$ & 97.1 & 2.5 & .4 & \\
\hline \multirow{2}{*}{$\begin{array}{l}\text { Primary medical } \\
\text { care available on } \\
\text { site }\end{array}$} & $\mathrm{F}$ & 477 & 3 & - & \multirow[t]{2}{*}{$468.08 *$} \\
\hline & $\%$ & 99.4 & .6 & - & \\
\hline \multirow{2}{*}{$\begin{array}{l}\text { Access to medical } \\
\text { room during } \\
\text { working hours }\end{array}$} & $\mathrm{F}$ & 473 & 7 & - & \multirow[t]{2}{*}{$452.41 *$} \\
\hline & $\%$ & 98.5 & 1.5 & - & \\
\hline \multirow{2}{*}{$\begin{array}{l}\text { Adequate no of rest } \\
\text { rooms In factory }\end{array}$} & $\mathrm{F}$ & 464 & 16 & - & \multirow[t]{2}{*}{$418.13 *$} \\
\hline & $\%$ & 96.7 & 3.3 & - & \\
\hline \multirow{2}{*}{$\begin{array}{ll}\text { Prevalence } & \text { of } \\
\text { Safety education or } \\
\text { training program }\end{array}$} & $\mathrm{F}$ & 473 & 2 & 5 & \multirow[t]{2}{*}{ 918.49* } \\
\hline & $\%$ & 98.5 & .4 & 1.0 & \\
\hline \multirow{2}{*}{$\begin{array}{l}\text { Issue of personal } \\
\text { protective } \\
\text { equipments free of } \\
\text { cost }\end{array}$} & $\mathrm{F}$ & 479 & 1 & - & \multirow[t]{2}{*}{$476.01 *$} \\
\hline & $\%$ & 99.8 & .2 & - & \\
\hline \multirow{2}{*}{$\begin{array}{l}\text { Firefighting } \\
\text { program }\end{array}$} & $\mathrm{F}$ & 477 & 3 & - & \multirow[t]{2}{*}{$468.08 *$} \\
\hline & $\%$ & 99.4 & .6 & - & \\
\hline \multirow{2}{*}{$\begin{array}{l}\text { Marking of } \\
\text { emergency exists. }\end{array}$} & $\mathrm{F}$ & 474 & 6 & - & \multirow[t]{2}{*}{$456.30^{*}$} \\
\hline & $\%$ & 98.8 & 1.3 & - & \\
\hline \multirow[t]{2}{*}{ Crèche facilities } & $\mathrm{F}$ & 480 & 0 & - & - \\
\hline & $\%$ & 100.0 & 0 & - & - \\
\hline
\end{tabular}

Note: F-frequency; ${ }^{*}$-Sig at .001 level

When Pregnant workers given proper care \& treatment was questioned, most of the respondents selected indicated 'yes' (93.5\%), 6.5\% of them said 'No'. Further, chi-square test revealed a significant difference between groups of frequencies of 'yes' \& 'no' responses $\left(X^{2}=193.663 ; p=.00\right)$, confirming that Pregnant workers given proper care \& treatment by management.

Maintenance of job position, wage \& benefits after maternity was questioned, majority of the respondents selected indicated 'yes' $(97.1 \%), 2.5 \%$ of them said 'No' and remaining .4 were not aware about it. Further, chisquare test revealed a significant difference between groups of frequencies of 'yes', 'no' \& 'Not aware' $\left(\mathrm{X}^{2}=878.150\right.$; $\mathrm{p}=.00$ ), confirming majority of them got the maintenance of job position, wage $\&$ benefits after maternity.

ESI Coverage for workers was asked, majority of the respondents selected indicated 'yes' (97.1\%), 2.5\% of them said 'No' and remaining .4 were not aware about it. Further, 
chi-square test revealed a significant difference between groups of frequencies of 'yes', 'no'\& 'Not aware' $\left(X^{2}=878.150 ; \mathrm{p}=.00\right)$, confirming that more than $4 / 5^{\text {th }}$ of them mentioned that ESI coverage for workers was existing.

When Primary medical care available on site was questioned, majority of the respondents selected indicated 'yes' (99.4\%), remaining .6\% of them said 'No'. Further, chi-square test revealed a significant difference between groups of frequencies of 'yes', 'no' \& 'Not aware' $\left(\mathrm{X}^{2}=468.075 ; \mathrm{p}=.00\right)$, confirming almost all of them mentioned that Primary medical care was available on site for workers.

When Access to medical room during working hours was asked, majority of the respondents selected indicated 'yes' $(98.5 \%)$, remaining 1.5 of them said 'No'. Further, chisquare test revealed a significant difference between groups of frequencies of 'yes' ',no' \& 'Not aware' $\left(\mathrm{X}^{2}=452.408\right.$; $\mathrm{p}=.00$ ), confirming that more than $4 / 5^{\text {th }}$ of them mentioned that Primary medical care was available on site for workers.

When Adequate no of rest rooms in factory was questioned, majority of the respondents selected indicated 'yes' (96.7\%), $3.3 \%$ of them said 'No'. Further, chi-square test revealed a significant difference between groups of frequencies of 'yes' \& 'no' $\left(\mathrm{X}^{2}=418.133 ; \mathrm{p}=.00\right)$, confirming that more than $4 / 5^{\text {th }}$ of them mentioned that Adequate number of rest rooms were there in the factory.

When Prevalence of Safety education or training program was questioned, majority of the respondents selected indicated 'yes' (98.5\%), .4\% of them said 'No' and remaining $1 \%$ have mentioned 'Not Aware'. Further, chisquare test revealed a significant difference between groups of frequencies of 'Yes', 'No' \& Not aware $\left(X^{2}=918.488\right.$; $\mathrm{p}=.00$ ), confirming that more than $4 / 5^{\text {th }}$ of them mentioned that Prevalence of Safety education or training program was there in the factory.

When Issue of personal protective equipment free of cost was asked, majority of the respondents selected indicated 'yes' (99.8\%), remaining .2\% of them said 'No'. Further, chi-square test revealed a significant difference between groups of frequencies of 'Yes', 'No' \& Not aware $\left(X^{2}=476.008 ; p=.00\right)$, confirming that more than $4 / 5^{\text {th }}$ of them mentioned that Issue of personal protective equipment was free of cost by the factory.

When Firefighting program was asked, majority of the respondents selected indicated 'yes' (99.4\%), remaining .6\% of them said 'No'. Further, chi-square test revealed a significant difference between groups of frequencies of 'Yes' \& 'No' $\left(\mathrm{X}^{2}=468.075 ; \mathrm{p}=.00\right)$, confirming that more than $4 / 5^{\text {th }}$ of them mentioned that Issue of personal protective equipment was free of cost by the factory.

When Marking of emergency exists was questioned, majority ofthe respondents selected indicated 'yes' (98.8\%), $1.3 \%$ of them said 'No'. Further, chi-square test revealed a significant difference between groups of frequencies of 'yes' \& 'no' $\left(\mathrm{X}^{2}=456.300 ; \mathrm{p}=.00\right)$, confirming that more than $4 / 5^{\text {th }}$ of them mentioned that Marking of emergency exists is done.
The entire selected sample indicated that they have Crèche facilities given by their respective managements.

\section{Harassment \& abuse}

Table2

Frequency and percent responses for various statements onHarassment \& abuseand results of chi-square tests.

\begin{tabular}{|c|c|c|c|c|c|}
\hline Statement & & Yes & No & $\begin{array}{l}\text { Not } \\
\text { aware }\end{array}$ & $\begin{array}{l}\text { Chi- } \\
\text { square }\end{array}$ \\
\hline \multirow{2}{*}{$\begin{array}{l}\text { Existence of } \\
\text { defined } \\
\text { disciplinary } \\
\text { system }\end{array}$} & $\mathrm{F}$ & 55 & 424 & 1 & \multirow[t]{2}{*}{$662.51^{*}$} \\
\hline & $\%$ & 11.5 & 88.3 & .2 & \\
\hline \multirow{2}{*}{$\begin{array}{l}\text { Physical, } \\
\text { psychological, } \\
\text { sexual, verbal } \\
\text { harassment? }\end{array}$} & $\mathrm{F}$ & 60 & 420 & - & \multirow[t]{2}{*}{$270.00 *$} \\
\hline & $\%$ & 12.5 & 87.5 & - & \\
\hline \multirow{2}{*}{$\begin{array}{l}\text { Received any } \\
\text { Disciplinary } \\
\text { notice }\end{array}$} & $\mathrm{F}$ & 4 & 471 & 5 & \multirow[t]{2}{*}{$906.76^{*}$} \\
\hline & $\%$ & .8 & 98.1 & 1.0 & \\
\hline \multirow{2}{*}{$\begin{array}{l}\text { Penalizing for } \\
\text { poor performance }\end{array}$} & $\mathrm{F}$ & 4 & 470 & 6 & \multirow[t]{2}{*}{$900.95 *$} \\
\hline & $\%$ & .8 & 97.9 & 1.3 & \\
\hline
\end{tabular}

Note: F-frequency; *-Sig at .001 level

Following the pattern of responses were observed for the question Existence of defined disciplinary system, most of the worker sample mentioned 'No' (88.3\%) $11.5 \%$ mentioned 'Yes' and remaining .2\% were not aware of it. Further, chi square test revealed a significant difference between groups of frequencies of 'yes' and 'no' and 'not aware' $\left(\mathrm{X}^{2}=662.513 ; \mathrm{p}=.000\right)$ responses confirming that more than $3 / 4^{\text {th }}$ of the respondents were informed that there is existence of defined disciplinary system in the factory.

When Physical, psychological, sexual, verbal harassment was questioned, majority of the worker sample indicated 'No' $(87.5 \%), 12.5 \%$ of remaining respondents said 'yes' by claiming that they faced harassment at work place. Further, chi-square test revealed a significant difference between groups of frequencies of 'yes' \& 'no' $\left(X^{2}=270.000 ; p=.00\right)$, confirming that more than $4 / 5^{\text {th }}$ of them mentioned that there is no harassment at work place.

When Disciplinary notice was questioned majority of the respondents mentioned 'No' (98.1\%), followed by 'yes' with $.8 \%$ and remaining $1 \%$ were not aware of it. Further, chi square test revealed a significant difference between groups of frequencies of 'yes' and 'no' and 'not aware' $\left(\mathrm{X}^{2}=\right.$ $906.763 ; p=.000)$ responses confirming that more than $3 / 4^{\text {th }}$ of the respondents informed that they did not receive any Disciplinary notice.

When Penalizing for poor performance was questioned, majority of the respondents mentioned 'No' (97.9\%), followed by 'yes' with $.8 \%$ and remaining $1.3 \%$ were not aware of it. Further, chi square test revealed a significant difference between groups of frequencies of 'yes' and 'no' and 'not aware' $\left(X^{2}=900.950 ; p=.000\right)$ responses confirming 
that more than $3 / 4^{\text {th }}$ of the respondents informed that they were not penalized for poor performance.

\section{Discussion}

\section{Major findings}

1. All the facilities related to health and safety was addressed $100 \%$ including no restriction to use bathroom facilities.

2. Most of crèche and canteen facilities were maintained except for Restrictions to workers to leave the child in crèche $(79.1 \%)$.

3. Majority of the workers (94.6) mentioned that they were not satisfied with the hygienic conditions of the canteen.

4. Only $1 / 8(12.5 \%)$ of the respondents indicated physical, psychological, secular and verbal harassment.

The data analysis relating to three major factors of welfare such as safety and Hygiene,Crèche and Canteen facilities were found to be satisfactory. However, there is a need for improvement in canteen facilities, this observation/finding mainly depend on the data collected through primary investigation employing questionnaire and conducting oral interview.

Some of the studies have revealed the following Barnes and Kozar $^{6}$ (2008), reported that pregnant women continually face abuse and discrimination in the garment industry. Many forms of exploitation/violence occur, including forced abortions, unpaid and/or required overtime, lack of required benefits, unfair hiring and promotion practices, and forced job assignments requiring intense physical labor which proves dangerous to the health and well-being of the worker and child in the uterus.

Discussing the importance of the labour welfare, Edwards ${ }^{7}$ (1953) said: "One can buy a man's time, his physical presence at a particular space, even a few muscular movements, but enthusiasm, initiative, loyalty and devotion to duty cannot be bought. They will have to be created through right employer-employee relations, provision of constructive opportunities for satisfying the major motivating desires of human action. “

\section{Conclusions}

In the economy of the country, contribution of garment industry is immense, Karnataka state is not exceptional. Bangalore city is contributing to the large extent in garment manufacturing activity. In the process of production, majority of labor force is women. This study is made to understand the welfare measures through the statistically proved as satisfactory. There is always a need for further improvement in the facilities extended. There is a scope for further research in this area taking into consideration of various other factors which are part of welfare measures. Harassment of these workers is reported less.

In the present situation providing good working condition,creating satisfactory working environment, taking care of health, emotion of employees, motivation to improve the productivity are important and also mandatory.The contribution of the textile industry in the state economy is significant and gives ample of employment opportunities to women force especially new literates and people with less than P.U education.The study is confined to the workers of selected five units in the industry and believes they are representing all units in the Bangalore city.

\section{References}

[1] D.S. Padmini and A. Venmathi A, "Unsafe Work Environment in Garment Industries, Tirupur, India”. J. Environ. Res Develop., 7(1A), pp. 569-575, 2012.

[2] B. Joseph, and P.R. Kiran, P.R.”A Stitch In Time". Annual Health Appraisal Of Garment Industry Employees. Pak J Med Sci., 24(1), pp. 104-108, 2008.

[3] D. Shanbhag, and B. Joseph, B. "Mental Health Status of Female Workers in Private Apparel Manufacturin Industry in Bangalore City,Karnataka, India". IntJ Collaborative Research on Internal Medicine \& Public Health.4(12), pp. 1893-1900, 2012.

[4] D.R.Adhikari, K. Hirasawa, Y.Takakubo, and .L. Pandey, D. L. "Decent work and work lifquality in Nepal : an observation" Employee relations, (1), pp 61-79, 2012

[5] D.R.Adhikari "Status of corporate social responsibility in selected Nepalese companies", Corporate Governance: The international journal of business in society, 12 (5), pp.642-655, 2012.

[6] W.D. Barnes, and J. .M.Kozar. "The exploitation of pregnant workers in apparel production", Journal of Fashion Marketing and Management: An International Journal, 12 (3), $285-$ 293,2008

[7] Edwards S.T. 'Philosophies of LabourWelfare'.Indian Journal of Social Work, 14(1), pp. 44-50, 1953.

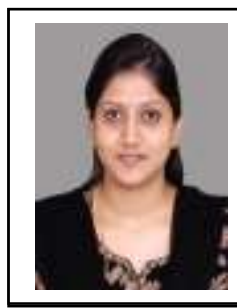

"Dedicated to all the women employees of garment industries and hoping that there will be a tremendous improvement in their work culture and betterment of their quality of life".

-Hemamalini, M.J. 